\title{
Ontslagrecht volgens de Commissie Regulering van Werk; een reflectie
}

\author{
mr. dr. Vivian Bij de Vaate*
}

\section{Inleiding}

Op 23 januari 2020 was het zover. De Commissie Regulering van Werk - ook wel, naar de voorzitter, Commissie-Borstlap genoemd - presenteerde haar eindrapport. ${ }^{1}$ Deze door het kabinet ingestelde onafhankelijke Commissie was de vraag voorgelegd of de huidige wet- en regelgeving van werk voldoende toegesneden is op de toekomstige behoeften en omstandigheden en indien dat niet het geval is, welke oplossingen er zijn om de knelpunten voor nu en de toekomst weg te nemen. ${ }^{2}$ De Commissie is ferm; de waarden van werk worden door de huidige regelgeving onvoldoende gewaarborgd en er zijn fundamentele aanpassingen nodig. De Commissie doet onder andere voorstellen tot aanpassing van het ontslagrecht. In het Tijdschrift voor Ontslagrecht kan een bespreking van die voorstellen niet ontbreken. In deze bijdrage wordt daaraan aandacht besteed en worden de plannen van een kritische reflectie voorzien. Daarbij zij vooraf opgemerkt dat de Commissie heeft ingezet op richtinggevende bouwstenen en maatregelen. ${ }^{3}$ De technische invulling van de voorgestelde maatregelen moet nog verder doordacht en uitgewerkt worden door de wetgever. Ook in dat kader kan deze bijdrage ter inspiratie dienen. Alvorens in te gaan op de voorgestelde wijzigingen voor het ontslagrecht, wordt kort stilgestaan bij de achtergrond van de wijzigingsvoorstellen met betrekking tot het ontslagrecht: de problemen op de arbeidsmarkt waaraan de Commissie door haar advies met onder andere een aanpassing in het ontslagrecht het hoofd wil bieden. Afgesloten wordt met een conclusie.

* Vivian Bij de Vaate is universitair docent bij de sectie Sociaal recht aan de Vrije Universiteit Amsterdam.

1. 'In wat voor land willen wij werken? Naar een nieuw ontwerp voor de regulering van werk', Eindrapport van de Commissie Regulering van Werk, 23 januari 2020 (hierna: Eindrapport).

2. Stcrt. 2018, 64352. Tegelijkertijd heeft een VAAN-VvA-expertgroep op eigen initiatief uitgangspunten voor een toekomstbestendig arbeidsrecht uitgewerkt in een zogenoemd 'Wetboek van Werk' (november 2019). https://www.wetboekvanwerk.nl/media/files/Wetboek\%20van \%20werk\%20concept\%20design\%20november \%202019\%20LabourLawLands\%20Editie\%20(1).pdf.

3. Eindrapport, p. 14

\section{Achtergrond}

De Commissie Regulering van Werk identificeert vijf kernproblemen in de huidige wet- en regelgeving van werk: (i) duurzame arbeidsrelaties worden ontmoedigd en externe flexibiliteit wordt gestimuleerd, (ii) het stelsel van contractvormen is onoverzichtelijk en moeilijk handhaafbaar, (iii) het aanpassingsvermogen van werkenden wordt onvoldoende geborgd, (iv) er zijn flinke verschillen tussen werkenden in de fiscale behandeling van werk en in inkomensbescherming en (v) het socialezekerheidsstelsel is te weinig proactief. ${ }^{4}$ De voorgestelde aanpassingen in het ontslagrecht hangen vooral samen met het eerste gesignaleerde knelpunt, dat hieronder nader uitgewerkt wordt.

De Commissie geeft aan dat er in Nederland op dit moment veel keuzevrijheid is in contractvormen die zien op het verrichten van werk, terwijl de risico's en kosten per contractvorm aanzienlijk verschillen. Aan de ene kant van het spectrum een arbeidsovereenkomst voor onbepaalde tijd met een vaste arbeidsurenomvang, een naar tijdruimte vastgesteld loon en ontslagbescherming en aan de andere kant een arbeidsovereenkomst voor bepaalde tijd zonder vaste arbeidsurenomvang en varianten van uitzendovereenkomsten zonder ontslagbescherming. Daarnaast bestaat ook de mogelijkheid om het werk door een zelfstandige te laten verrichten. ${ }^{5}$ Doordat de arbeidsovereenkomst voor onbepaalde tijd een 'stapel' van verantwoordelijkheden voor werkgevers met zich brengt, is het angaan van een dergelijke overeenkomst relatief onaantrekkelijk voor werkgevers. ${ }^{6}$ In plaats daarvan wordt steeds meer werk verricht op basis van een flexibel contract (alle contractvormen niet zijnde een contract voor onbepaalde tijd). Die flexibilisering heeft nadelige sociale en maatschappelijke effecten. ${ }^{7} \mathrm{Zo}$ heeft de groep van flexibel werkenden een grotere kans om werkloos te worden, ${ }^{8}$ verdienen zij minder voor hetzelfde werk $^{9}$ en is de kans op armoede drie keer zo hoog. ${ }^{10}$ Bovendien betaalt ook het collectief een hogere prijs voor flexibel werk; flexibel werkenden doen vaker een beroep op collectieve regelingen rondom werkloos-

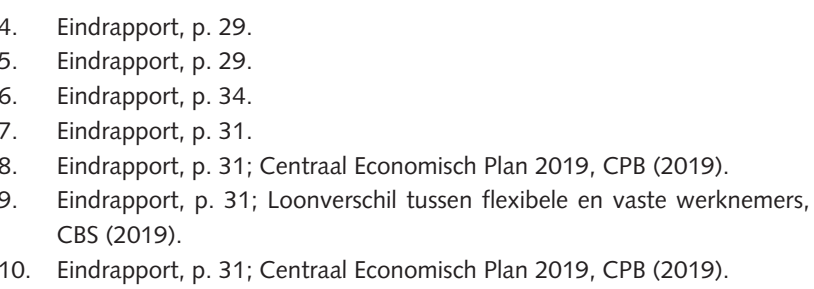


heid, ziekte en arbeidsongeschiktheid en bijstand. ${ }^{11}$ Daarnaast constateert de Commissie dat flexwerk steeds vaker structureel van aard is en steeds minder een opstap vormt naar een arbeidsovereenkomst voor onbepaalde tijd. ${ }^{12}$ Bovendien concentreert flexwerk zich met name bij werknemers met een minder sterke positie op de arbeidsmarkt. Dit leidt ertoe dat juist diegenen met een zwakkere sociaal-economische positie, voor wie arbeidsrechtelijke bescherming en een adequaat sociaal vangnet bij uitstek bedoeld zijn, daaraan steeds minder zekerheid ontlenen. ${ }^{13}$ Ten slotte ondermijnt flexibilisering het verdienvermogen. Duurzame arbeidsrelaties, waarin werkgever en werknemer voor langere tijd aan elkaar verbonden zijn, zijn geschikter om over en weer te investeren in de ontwikkeling van menselijk en organisatiekapitaal. ${ }^{14}$

Het voorgaande leidt tot de conclusie dat de verdeling tussen wendbaarheid en zekerheid in arbeidsrelaties uitermate ongelijk verdeeld is. Er moet naar een nieuw evenwicht gezocht worden. Volgens de Commissie moeten de regels zo worden ingericht dat zij arbeidsovereenkomsten voor onbepaalde tijd bevorderen, waarbij werkgevers binnen de arbeidsovereenkomst voor onbepaalde tijd voldoende wendbaarheid wordt gegeven en externe flexibiliteit wordt afgeremd. ${ }^{15}$ Dit heeft volgens de Commissie als logische eerste consequentie (i) dat het werkgeverschap moet worden ontlast en de manoeuvreerruimte binnen de arbeidsovereenkomst voor onbepaalde tijd vergroot dient te worden. ${ }^{16}$ Daartoe adviseert de Commissie allereerst om de loondoorbetalingsperiode bij ziekte te verkorten tot een jaar. Daarnaast stelt de Commissie voor de werkgever de mogelijkheid te geven om de arbeidsvoorwaarden eenzijdig te wijzigen indien bedrijfseconomische omstandigheden daartoe aanleiding geven. Verder adviseert de Commissie de Wet flexibel werken meer onder de aandacht van werkgevers en werknemers te brengen. Ook de aanpassing van het ontslagrecht, waarop in de volgende paragraaf nader wordt ingegaan, is een voorgestelde maatregel om het werkgeverschap te ontlasten en interne wendbaarheid te bevorderen. ${ }^{17}$ Ten tweede (ii) doet de Commissie de

11. Eindrapport, p. 32; De sociaal-economische situatie van langdurig flexibele werknemers, SEO (2019).

12. Eindrapport, p. 32; Vraag naar arbeid 2013, SCP (2014).

13. Eindrapport, p. 34; Arbeidsdeelname; onderwijsniveau CBS (2018); Centraal Economisch Plan, CPB (2019).

14. Eindrapport, p. 37; Michie \& Sheehan, 'Labour market deregulation, "Flexibility" and innovation', Cambridge Journal of Economics 2203-1; Forrier \& Sels, 'Temporary employment and employability: Training opportunities and efforts of temporary and permanent employees in Belgium', Work, Employment and Society 2003-4.

15. Eindrapport, p. 64. Dit is wat de Commissie als bouwsteen 1 kenschetst om de door de Commissie geadviseerde richting aan te geven voor regels rondom werk. Daarnaast reikt de Commissie vier andere bouwstenen aan corresponderend met de knelpunten ii tot en met $v$ die zij identificeert. Het gaat achtereenvolgens om: (ii) creëer een overzichtelijker stelsel van contractvormen, (iii) stel alle werkenden in staat zich te ontwikkelen en te (blijven) leren, (iv) zorg voor een fiscaal gelijke behandeling van en basisinkomenszekerheid voor alle werkenden, (v) kom tot een activerend en inclusief arbeidsmarktbeleid.

16. Eindrapport, p. 64.

17. Eindrapport, p. 65-66. aanbeveling om tijdelijke arbeidsovereenkomsten nog verder te beprijzen dan thans al het geval is via de door de Wet arbeidsmarkt in balans ingevoerde premiedifferentiatie. De beloning van de werknemer met een flexibel contract dient te corresponderen met de grotere risico's die deze werknemer draagt. Daarbij kan gedacht worden aan het toekennen van een hoger wettelijk minimumloon of aan een flex-toeslag. ${ }^{18}$ Ten slotte (iii) dient gewaarborgd te worden dat tijdelijk werk ook echt tijdelijk wordt ingezet. Het opnemen van een specifieke rechtvaardigingsgrond voor tijdelijk werk is naar het oordeel van de Commissie echter geen goede optie, omdat het in de praktijk lastig te handhaven is. De Commissie adviseert, als een second-best, in te zetten op het verkorten van de duur van de ketenregeling naar twee jaar. De termijn van drie jaar, die sinds 1 januari 2020 weer geldt als gevolg van de inwerkingtreding van de Wet arbeidsmarkt in balans, is volgens de Commissie een te ruime opvatting van 'tijdelijk werk'. ${ }^{19}$ Verder stelt de Commissie voor om in de definitie van de uitzendovereenkomst een allocatiefunctie op te nemen en uitzending naar een specifieke opdrachtgever slechts tijdelijk mogelijk te laten zijn, om zo te voorkomen dat werknemers structureel bij een derde kunnen worden tewerkgesteld. ${ }^{20}$ Ten slotte adviseert de Commissie de mogelijkheden tot het aangaan van arbeidsovereenkomsten zonder vaste arbeidsurenomvang te beperken. De stappen die daartoe reeds gezet zijn met de Wet arbeidsmarkt in balans acht de Commissie nog niet afdoende. De Commissie adviseert om het wettelijk niet langer mogelijk te maken om de loondoorbetalingsplicht uit te sluiten als er niet wordt gewerkt vanwege een oorzaak die ligt in de risicosfeer van de werkgever. Bovendien dient in elke arbeidsovereenkomst minimaal per kwartaal een vast aantal arbeidsuren overeengekomen te worden. ${ }^{21}$

\section{Voorgestelde aanpassing van het ontslagrecht}

Binnen een nieuw evenwicht tussen externe flexibiliteit en interne wendbaarheid past een aanpassing van het ontslagrecht. Volgens de Commissie is de stap die met de Wet arbeidsmarkt in balans is gezet, door de hoogte van de transitievergoeding te verlagen en de introductie van de cumulatiegrond als redelijke grond voor ontslag, nog niet voldoende. De voorgestelde aanpassing gaat uit van het behoud van de preventieve toets. Ook ziet de Commissie geen aanleiding tot aanpassing van het ontslagrecht bij bedrijfseconomische omstandigheden. De huidige systematiek voorkomt willekeur door middel van het afspiegelings- en anciënniteitsbeginsel en dat

\footnotetext{
18. Eindrapport, p. 67

19. Eindrapport, p. 67

20. Eindrapport, p. 67.

21. Eindrapport, p. 68
} 
dient behouden te blijven. ${ }^{22}$ Wel ziet de Commissie reden om te sleutelen aan de sanctie op het ontbreken van een in de persoon van de werknemer gelegen ontslaggrond (de c- tot en met i-grond). In het huidige ontslagrecht kan de kantonrechter de arbeidsovereenkomst niet ontbinden als een redelijke grond ontbreekt en de werknemer stelt zijn baan te willen behouden. Dit past volgens de Commissie niet goed binnen de wendbaarheid van de werkgever die de Commissie voor ogen staat. De Commissie stelt dan ook voor dat de kantonrechter de arbeidsovereenkomst op verzoek van de werkgever altijd ontbindt, als de werkgever de arbeidsovereenkomst wil beëindigen wegens de c- tot en met igrond, tenzij het verzoek verband houdt met een opzegverbod. Oordeelt de kantonrechter dat de werkgever geen redelijke grond heeft voor het ontslag, dan is de werkgever een punitieve vergoeding verschuldigd aan de werknemer. Dit laatste moet lichtvaardige ontbindingsverzoeken voorkomen. ${ }^{23}$

Verder wil de Commissie deeltijdontslag mogelijk maken. Dit loopt via de band van de eenzijdige wijziging. De Commissie wil het mogelijk maken om ook op het terrein van arbeidsomvang, salaris, functie, werklocatie en arbeidstijden de arbeidsovereenkomst eenzijdig te wijzigen indien bedrijfseconomische omstandigheden daartoe aanleiding geven. In de kern dient het erop neer te komen dat de werkgever de werknemer een aanbod tot wijziging van de arbeidsovereenkomst op voormelde onderdelen kan doen en de werknemer dit aanbod dient te accepteren, tenzij sprake is van zwaarwegende belangen aan zijn kant. De werkgever kan een dergelijk aanbod niet onbeperkt doen, maar - afhankelijk van de betrokken arbeidsvoorwaarde - bijvoorbeeld eens per jaar of twee jaar. ${ }^{24}$

Ten slotte stelt de Commissie voor om te waarborgen dat de transitievergoeding niet meer vrij kan worden aangewend, maar moet leiden tot extra leerrechten voor de werknemer. ${ }^{25}$ Zo draagt de transitievergoeding beter bij aan het beoogde doel: de transitie van werk naar werk. Dit voorstel hangt samen met het door de Commissie gesignaleerde knelpunt dat in de huidige regelgeving het aanpassingsvermogen van werkenden onvoldoende wordt geborgd. ${ }^{26}$ Werkenden moeten in de toekomst beter beschermd zijn tegen het risico op kennisveroudering. De Commissie doet de aanbeveling om aan alle werkenden een individueel ontwikkelbudget toe te kennen en een loopbaanwinkel te creëren die werkenden ondersteunt bij het gebruikmaken van dat ontwikkelbudget. De transitievergoeding die de werkgever verschuldigd is bij het beëindigen van de arbeidsovereenkomst wordt toegevoegd an dat persoonlijk ontwikkelbudget. ${ }^{27}$

\section{Commentaar}

4.1. Behoud preventieve toets en deeltijdontslag De Commissie gaat uit van het behoud van de preventieve ontslagtoets door de kantonrechter en het UWV. ${ }^{28}$ Dat sluit mijns inziens goed aan bij de waarden van werk die de Commissie identificeert, zijnde een van de belangrijkste aspecten van het menselijk bestaan en de menselijke waardigheid; voor zelfontplooiing, gezondheid en individueel welbevinden. ${ }^{29}$ Bovendien past het goed in de door de Commissie geformuleerde doelstelling van het vergroten van de opeisbaarheid van rechten voor alle werkenden, in het bijzonder voor diegenen met een sociaal-economisch zwakkere positie, voor wie het complex is inzicht te hebben in hun rechten en voor wie het te kostbaar is om hun recht te halen. ${ }^{30}$ Ter realisatie van deze doelstelling, die de Commissie hanteert ter oplossing van het knelpunt dat het huidige stelsel van contractvormen onoverzichtelijk en moeilijk handhaafbaar is, adviseert de Commissie om voor alle werkenden een publiek loket op te richten waar zij op een laagdrempelige wijze inzicht kunnen krijgen in hun rechten en waar ondersteuning geleverd kan worden bij de effectueren van die rechten, zoals bijvoorbeeld een arbeidsombudsman. ${ }^{31}$ Het behoud van de preventieve ontslagtoets voor alle werkenden met een arbeidsovereenkomst voor onbepaalde tijd draagt mijns inziens ook in belangrijke mate bij aan de opeisbaarheid van rechten. Door de preventieve toets wordt de werknemer beschermd tegen willekeur door de werkgever bij het verbreken van de arbeidsovereenkomst. De redelijke grond voor ontslag moet altijd worden getoetst voordat de werkgever tot eenzijdig ontslag kan overgaan. Nadeel van de in andere landen gebruikelijke repressieve ontslagtoets is dat de werknemer achteraf zijn recht moet halen door het aanhangig maken van een procedure. Zoals de Commissie ook angeeft, zal dit zeker voor de lager betaalde werknemer veelal geen optie zijn. Zelfs als deze de procedure wint, komen de eigen advocaatkosten volledig voor rekening van de werknemer. ${ }^{32}$ De kans is daardoor groot dat met een louter repressieve toetsing veel 'onredelijke ontslagen' van met name werknemers met een zwakkere sociaal-economische positie nooit ter toetsing van de rechter komen.

28. De VAAN-VvA-expertgroep gaat in het 'Wetboek van Werk' (november 2019) juist uit van de afschaffing van de preventieve ontslagtoets, met als belangrijkste argumenten dat de preventieve toets oorspronkelijk bedoeld was als een tijdelijke maatregel en dat die preventieve toets internationaal gezien ongebruikelijk is. Zie Wetboek van Werk, p. 29. In plaats daarvan gaat zij uit van een repressieve toetsing van een redelijke grond voor ontslag voor alle werkrelaties (ook voor het niet continueren van een contract voor bepaalde tijd). De intensiteit van de toetsing of zich een redelijke grond voor ontslag voordoet, zal variëren naargelang de band tussen werkverschaffer en werker duurzamer is. Zie Wetboek van Werk, p. 30

29. Eindrapport, p. 7 en 17

30. Eindrapport, p. 76.

31. Eindrapport, p. 76

32. Eindrapport, p. 66 
Het uitgangspunt tot behoud van de preventieve ontslagtoets met bijbehorende argumenten wordt niet consistent doorgetrokken in het advies van de Commissie. Dat brengt mij bij de regeling die de Commissie introduceert omtrent deeltijdontslag. Om de interne wendbaarheid voor werkgevers binnen contracten voor onbepaalde tijd te vergroten en externe flexibiliteit een halt toe te roepen, stelt de Commissie voor dat werkgevers de mogelijkheid krijgen om eens per jaar of twee jaar een aanbod tot wijziging van de arbeidsovereenkomst te doen op het terrein van arbeidsomvang, salaris, functie, werklocatie of arbeidstijden en de werknemer dit aanbod dient te accepteren, tenzij sprake is van zwaarwegende belangen aan zijn kant. De Commissie merkt op dat deze regeling een deeltijdontslag mogelijk makkt, maar meent dat dit noodzakelijk is voor een nieuw evenwicht tussen externe flexibiliteit en interne wendbaarheid. De werkgever moet de mogelijkheid hebben om de arbeidsorganisatie aan te passen in geval van veranderende omstandigheden zoals fluctuaties in de vraag naar producten of diensten. Wel merkt de Commissie op dat zij zich realiseert dat een deeltijdontslag gepaard gaat met een teruggang in salaris, hetgeen voor een werknemer niet altijd eenvoudig zal zijn op te vangen. Deeltijdontslag zal dan ook volgens de Commissie met enige waarborgen moeten worden omkleed, zoals bijvoorbeeld een minimum aan inkomen dat moet overblijven, een inkomensgrens waaronder een deeltijdontslag niet is toegestaan en/of een trapsgewijze afbouw van het salaris. ${ }^{33}$ Wat echter ontbreekt in deze waarborgen is de preventieve toets door het UWV. Dat wordt expliciet gemaakt in het eindadvies van de Commissie. De Commissie adviseert:

'Introduceer de mogelijkheid van een deeltijdontslag (zonder preventieve toets) tot een bepaald percentage van de arbeidsduur wegens bedrijfseconomische omstandigheden (eventueel met een rol voor de ondernemingsraad). Werknemer moet aanbod accepteren, tenzij aan de kant van werknemer sprake is van zwaarwegende belangen'. ${ }^{34}$

Het mogelijk maken van een deeltijdontslag zonder de waarborg van een preventieve toetsing is niet consistent met de argumenten die ten grondslag liggen aan het behoud van het systeem van preventieve toetsing van ontslagen en mijns inziens vanuit handhavingsperspectief onrechtvaardig. Het argument voor het behoud van de preventieve ontslagtoets - dat het voor veel werknemers geen optie zal zijn om na het ontslag een gerechtelijke procedure aan te spannen - geldt namelijk nog sterker voor een werknemer die door de werkgever wordt geconfronteerd met een deeltijdontslag. Vergeleken met een werknemer die geconfronteerd wordt met een algeheel ontslag, geldt voor de werknemer die nog een gedeeltelijke dienstbetrekking heeft dat niet alleen een gebrek aan inzicht in zijn rechten en de hoge kosten

33. Eindrapport, p. 65.

34. Eindrapport, p. 87. van een procedure hem kunnen afhouden van het aanspannen van een procedure, maar belangrijker nog: de angst voor mogelijke repercussies door de werkgever. ${ }^{35}$ De Commissie merkt op dat een deeltijdontslag met teruggang in salaris de voorkeur heeft boven een aan de WW gekoppelde mogelijkheid van deeltijdontslag, omdat via een dergelijke regeling ondernemersrisico's kunnen worden afgewenteld op het collectief. ${ }^{36}$ Onduidelijk is wat hiermee precies bedoeld wordt, maar wanneer dit betekent dat de Commissie voor ogen heeft dat de werknemer die een deel van zijn dienstbetrekking is kwijtgeraakt, geen rechten aan de WW kan ontlenen voor het verloren gedeelte van de arbeidsovereenkomst, geldt het voorgaande in nog belangrijker mate.

Overigens heeft de Hoge Raad in zijn beschikking van 21 februari $2020^{37}$ geoordeeld dat een partiële ontbinding op grond van het huidige artikel 7:671b BW niet tot de mogelijkheden behoort, maar dat een gedeeltelijk ontslag wel door of op initiatief van partijen op andere manieren kan worden bewerkstelligd. Opvallend is dat een van die manieren volgens de Hoge Raad een wijziging van de arbeidsovereenkomst is op initiatief van de werkgever, op grond van de in het arrest Stoof/ Mammoet ${ }^{38}$ geformuleerde maatstaf. Kennelijk acht de Hoge Raad een vorm van het door de Commissie Regulering van Werk voorgestelde deeltijdontslag via de band van wijziging van de arbeidsovereenkomst reeds mogelijk in het huidige stelsel. Dit staat mijns inziens op gespannen voet met het systeem van preventieve toetsing van ontslagen zoals neergelegd in artikel 7:671 lid 1 en $7: 671 \mathrm{~b} \mathrm{BW}^{39}$ en de pendant daarvan in het huidige artikel 8 BBA $1945^{40}$ dat de werkgever verbiedt eenzijdig de arbeidstijd te verkorten voor zover een dergelijke verkorting gepaard gaat met een vermindering

35. Zie G. Davidov, 'The Enforcement Crisis in Labour Law and the Fallacy of Voluntarist Solutions', Int. J. of Comp. Lab. Law \& Ind. Rel. 2010/26; M. Barendrecht \& Y.P. Kamminga, Toegang tot recht: de lasten van een uitweg: Den Haag: RMO advies 2004, p. 61; J.G.J. Rinkes \& J.M.P. Verstappen, 'De toekomstige vormgeving van het civiele procesrecht', in: M.L. Hendrikse (red.), De toekomst van het Nederlands burgerlijk procesrecht, Deventer: Kluwer 2004, p. 98; J.M. Barendrecht \& E.J.M. van Beukering-Rosmuller, Recht rond onderhandeling: naar verbintenissenrecht, procesrecht en rechtspraktijk die sporen met moderne geschiloplossingsmethoden, Den Haag: Boom juridische uitgevers 2000.

36. Eindrapport, p. 65

37. HR 21 februari 2020, ECLI:NL:HR:2020:283.

38. HR 11 juli 2008, ECLI:NL:HR:2008:BD1847.

39. Vgl. Rb. Amsterdam 16 juli 2018, ECLI:NL:RBAMS:2018:5052 (het ontbreken van toestemming van het UWV voor deeltijdontslag kan niet gerepareerd worden met een beroep op art. 7:613 BW).

40. De schrapping van art. 8 BBA 1945 als voorzien bij de Wwz is nog niet geëffectueerd. Het is de bedoeling dat een calamiteitenregeling WW wordt ingevoerd, waarmee art. 8 BBA 1945 komt te vervallen. De calamiteitenregeling zal de bevoegdheid van de werkgever regelen om de werktijd te verkorten (waarmee de verplichting tot betaling van het loon vervalt) als de arbeid geheel of gedeeltelijk niet kan worden verricht als gevolg van bij die regeling te bepalen buitengewone omstandigheden. Zie Kamerstukken I/ 2013/14, 33818, nr. 3, p. 88. De calamiteitenregeling zal in ieder geval niet voor 2022 in werking treden. Zie de toelichting bij Regeling onwerkbaar weer, Stcrt. 2019, 70095. 
van het loon. ${ }^{41}$ Toegegeven, de wijziging op grond van de maatstaf van Stoof/Mammoet, in tegenstelling tot het eenzijdigewijzigingsbeding als bedoeld in artikel 7:613 BW, berust uiteindelijk op wilsovereenstemming, in verband waarmee de voor werkgever en werknemer over en weer uit artikel 7:611 BW voortvloeiende verplichtingen van belang zijn. ${ }^{42}$ De verwachting is echter dat als de werknemer weigert het voorstel van de werkgever tot vermindering van de arbeidsduur en het loon te aanvaarden, de werkgever in de praktijk met deze uitspraak in de hand de vermindering van de arbeidsduur en het daarbij behorende loon eenzijdig zal doorvoeren, stellende dat de werknemer op grond van artikel 7:611 BW gehouden was akkoord te gaan met de wijziging. Dat omzeilt de preventieve toetsing van ontslagen en is in strijd met artikel 8 BBA 1945.

\subsection{Een stap verder naar werkzekerheid in plaats} van baanzekerheid

De Commissie stelt voor om de sanctie op het ontbreken van een in de persoon van de werknemer gelegen ontslaggrond aan te passen. De kantonrechter dient de arbeidsovereenkomst op verzoek van de werkgever op de c- tot en met i-grond altijd te ontbinden, mits het verzoek geen verband houdt met een opzegverbod. Het in stand houden van de arbeidsovereenkomst tegen de zin in van de werkgever, zoals thans het geval is bij het ontbreken van een redelijke grond en een werknemer die stelt dat hij zijn baan wil behouden, past minder goed binnen de wendbare organisatie die de Commissie voor ogen staat. ${ }^{43}$ Dit betekent niet dat de toetsing van de redelijke grond wordt losgelaten, hetgeen overigens ook op gespannen voet zou staan met bepalingen in het internationale en Europese recht die een 'geldige reden' voor ontslag en de toetsing daarvan door een onafhankelijke instantie voorschrijven. ${ }^{44}$ De redelijke grond wordt getoetst in het kader van de vraag of de werkgever een vergoeding verschuldigd is aan de werknemer. Is er geen redelijke grond voor ontslag, dan is de werkgever een vergoeding verschuldigd die volgens de Commissie een punitief karakter dient te hebben om te lichtvaardige ontbindingsverzoeken te voorkomen. ${ }^{45}$ Deze sanctie op het ontbreken van een redelijke grond kan internationaal gezien door de beugel. De bepalingen die een 'geldige

41. Wel kan van het verbod van werktijdverkorting voor bepaalde werknemers of groepen van werknemers voorwaardelijk of onvoorwaardelijk ontheffing worden verleend door de minister van SZW. Zie art. 8 lid 3 BBA 1945, Regeling Ontheffing van artikel 8 BBA 1945, Stcrt. 1985, 118 en Beleidsregeling ontheffing verbod op werktijdverkorting 2004, Stcrt. 2004, 199.

42. Vgl. W.H.A.C.M. Bouwens, R.A.A. Duk \& D.M.A. Bij de Vaate, Van der Grinten Arbeidsovereenkomstenrecht, Deventer: Wolters Kluwer 2018 p. 64.

43. Eindrapport, p. 66

44. Zie art. 4 ILO-verdrag nr. 158; art. 24 ESH en art. 30 Handvest EU.

45. Eindrapport, p. 66. Vgl. ook Wetboek van Werk (november 2019), p. 30. Volgens de VAAN-VvA-expertgroep moet de werker na repressieve toetsing van het ontslag de kans krijgen om zijn werkzaamheden te hervatten, indien een redelijke grond voor ontslag ontbreekt. Afkoop van werkhervatting in de vorm van een substantiële ontslagvergoeding aan de hand van een model, moet echter in uitzonderingsgevallen mogelijk zijn, omdat werkhervatting tegen wil en dank niet vruchtbaar voorkomt. reden' voor ontslag voorschrijven vereisen niet dat het ontbreken van een dergelijke 'geldige reden' alleen gesanctioneerd kan worden met een onmogelijkheid tot het verbreken van de arbeidsovereenkomst of een mogelijkheid tot vernietiging van de opzegging of herstel van de arbeidsovereenkomst. Een adequate vergoeding ter compensatie voor de onredelijkheid van het ontslag is afdoende. ${ }^{46}$

De voorstellen van de Commissie streven een verdere verschuiving van baanzekerheid ${ }^{47}$ naar werkzekerheid ${ }^{48}$ na. Stappen daartoe zijn reeds gezet met de Wet werk en zekerheid door de introductie van een scholingsplicht (art. 7:611a BW) en het recht op transitievergoeding (art. 7:673 BW). ${ }^{49} \mathrm{Nu}$ wordt een stap verder gegaan door voor te stellen dat de kantonrechter de arbeidsovereenkomst altijd op initiatief van de werkgever ontbindt indien de reden voor ontslag in de c- tot en met igrond is gelegen, met daarbij een afkoopsom voor het ontbreken van een voldragen ontslaggrond. Daar komt bij dat de Commissie ook aanbeveelt om aan iedere werkende een individueel ontwikkelbudget toe te kennen, waaraan ook de transitievergoeding wordt toegevoegd, een loopbaanwinkel te creëren die werkenden ondersteunt bij het gebruikmaken van het ontwikkelbudget en te komen tot een geïntegreerde aanpak om het risico op kennisveroudering tegen te gaan. ${ }^{50}$

Het per definitie ontbinden van de arbeidsovereenkomst op verzoek van de werkgever bij een c- tot en met igrond met een eventuele vergoeding voor de werknemer wanneer geen sprake is van een voldragen grond, is mijns inziens niet alleen in het belang van een wendbare organisatie, maar doet ook recht aan het werknemersperspectief. Het zal doorgaans ook voor de werknemer geen pretje zijn om de arbeidsovereenkomst voort te zetten wanneer de werkgever onsuccesvol heeft geprobeerd een ontbinding te bewerkstelligen. De onderlinge verhoudingen worden er niet beter op. ${ }^{51}$ In het huidige systeem ligt het in de rede dat werkgever en werknemer korte tijd daarna alsnog afscheid van elkaar nemen met behulp van een vaststellingsovereenkomst of een ontbinding wegens een verstoorde arbeidsverhouding, al dan niet in hoger beroep tegen de afwijzing van de ontbin-

46. Zie art. 10 ILO-verdrag nr. 158 en art. 24 sub b ESH.

47. Baanzekerheid wordt doorgaans uitgelegd als de zekerheid van behoud van de huidige dienstbetrekking. Zie N. Zekic, 'Ontslagbescherming in Nederland in dienst van baanzekerheid of werkzekerheid?', TvO 2019/3.

48. Werkzekerheid wordt doorgaans uitgedrukt als de zekerheid om aan het werk te blijven, maar niet noodzakelijkerwijs bij de dezelfde werkgever. Zie N. Zekic, 'Ontslagbescherming in Nederland in dienst van baanzekerheid of werkzekerheid?', TvO 2019/3.

49. Zie N. Zekic, 'Ontslagbescherming in Nederland in dienst van baanzekerheid of werkzekerheid?', TvO 2019/3.

50. Eindrapport, p. 76-77

51. Vgl. L.H. van den Heuvel, Ontslagrecht, Deventer: W.E.J. Tjeenk Willink 1996, p. 94; S.W. Kuip \& E. Verhulp, 'Vernietigbaarheid in het ontslagrecht: effectieve rechtsbescherming of fictie vol frictie', in: E. Lutjens (red.), De Le(e)nigheid van het Sociaal Recht, Liber Amicorum voor Leen van den Heuvel, Amsterdam: VU 2006, p. 259. 
dingsbeschikking in eerste aanleg. ${ }^{52}$ Bovendien werkt het huidige stelsel ernstig verwijtbaar handelen door de werkgever in de hand om op die manier een verstoorde arbeidsverhouding te forceren en een succesvolle ontbinding op de g-grond te kunnen bewerkstelligen. ${ }^{53}$ Het nieuw voorgestelde stelsel is in die zin efficiënter en voorkomt onnodig leed aan de kant van de werknemer. Het ontbreken van een redelijke grond kan afgekocht worden, zonder dat daarvoor ernstig verwijtbaar handelen door de werkgever noodzakelijk is. Het doet sterk denken aan de goed functionerende oude 685praktijk, alhoewel daar ongeveer 9\% van de ontbindingsbeschikkingen resulteerde in een afwijzing van de ontbinding. ${ }^{54}$

\subsection{De vergoeding als sanctie op het ontbreken van een $\mathrm{c}-\mathrm{t} / \mathrm{m}$ i-grond}

De voorgestelde vergoeding als sanctie op het ontbreken van een redelijke grond roept vragen op ter nadere uitwerking. Wanneer we uitgaan van de handhaving van het door de Wet werk en zekerheid en de Wet arbeidsmarkt in balans gecreëerde stelsel, dan betekent het voorstel dat we bovenop de verschillende soorten vergoedingen die we al kennen - de billijke vergoeding, de transitievergoeding, de extra i-grond-vergoeding en de onregelmatigheidsvergoeding - nog met een extra vergoeding te maken krijgen. ${ }^{55}$ Of het ontslagstelsel er daardoor eenvoudiger op wordt, zoals de Commissie voorstaat blijkens de titel van de paragraaf die gaat over de aanpassing, ${ }^{56}$ valt te bezien. Mijns inziens moet met name goed nagedacht worden over de verhouding tussen de vergoeding verschuldigd bij het ontbreken van een redelijke grond en de huidige billijke vergoeding die de werkgever verschuldigd is bij een ontbinding die het gevolg is van ernstig verwijtbaar handelen of nalaten door de werkgever. De Commissie merkt op dat de vergoeding die de werkgever verschuldigd is indien een redelijke grond voor ontslag ontbreekt, een punitief karakter dient te hebben om lichtvaardige ontbindingsverzoeken te voorkomen. Ten aanzien van de huidige billijke vergoeding wegens ernstig verwijtbaar handelen of nalaten heeft de Hoge Raad geoordeeld dat deze geen punitief karakter kent. ${ }^{57}$ Mijns inziens moet ervoor

52. Zie bijv. Hof Amsterdam 24 oktober 2017, ECLI:NL:GHAMS 2017:4337; Hof 'Den Bosch 28 september 2017, ECLI:NL:GHSHE: 2017:4153; Ktr. Amsterdam 29 januari 2016, ECLI:NL:RBAMS: 2016:400. Vgl. J.H. Bennaars, M. Diepenbach, R. Knegt \& E. Verhulp, Evaluatie ontslaggronden WWZ. Rapport, Amsterdam: UvA, Hugo Sinzheimer Instituut 2016, p. 10.

53. Zie bijv. Hof Arnhem-Leeuwarden 13 januari 2020, ECLI:NL:GHARL: 2020:247; Ktr. Rotterdam 20 december 2019, ECLI:NL:RBROT: 2019:10181; Hof Den Haag 26 november 2019, ECLI:NL:GHDHA 2019:3164; Ktr. Rotterdam 5 november 2019, ECLI:NL:RBROT: 2019:8666.

54. Zie P. Kruit \& C.J. Loonstra, 'Statistiek ontbindingsvergoedingen 2011 de representativiteit van de gepubliceerde ontbindingsbeschikkingen aangetoond', ArbeidsRecht 2012/22; P. Kruit, 'Statistiek ontbindingsvergoedingen 2012: het einde van een tijdperk "Loonstratistiek"', ArbeidsRecht 2013/32.

55. Vgl. F.M. Dekker \& Z. Even, 'VAAN - VvA - Wab - Cumulatiegrond en vergoeding, TAP 2018/153.

56. Zie Eindrapport, p. 66.

57. HR 30 juni 2017, ECLI:NL:HR:2017:1187 (New Hairstyle) gewaakt worden dat de billijke vergoeding wegens ernstig verwijtbaar handelen en de voorgestelde punitieve vergoeding wegens het ontbreken van een redelijke grond qua begroting en hoogte met elkaar uit de pas gaan lopen. De rechterlijke macht zal anders te maken krijgen met lastige afbakeningsvraagstukken en voorkomen moet worden dat ernstig verwijtbaar gedrag lonend is voor de werkgever. Neem een klassiek voorbeeld van de zogenoemde Asscher-escape: de werkgever meldt de werknemer van de ene op de andere dag dat hij disfunctioneert en drijft daarbij de zaak op de spits door de werknemer meteen te schorsen. Is dit nu een voldragen $\mathrm{g}$ - of i-grond, met een billijke vergoeding wegens ernstig verwijtbaar handelen door de werkgever? Of is hier nog geen sprake van een $\mathrm{g}$ - of $\mathrm{i}$-grond en dient er ontbonden te worden met de toekenning van de punitieve vergoeding wegens het ontbreken van een redelijke grond? Wanneer die punitieve vergoeding wegens het ontbreken van een redelijke grond hoger uitpakt dan de billijke vergoeding wegens ernstig verwijtbaar handelen, vormt dat een incentive voor de werkgever om in de gevallen waarin een redelijke grond ontbreekt, in het traject voorafgaand aan het ontbindingsverzoek dusdanig ernstig verwijtbaar te handelen dat daarmee een redelijke grond wordt gecreëerd.

\section{Afsluiting}

De Commissie Regulering van Werk heeft een voorstel gedaan voor onder andere een aanpassing van het ontslagrecht als een van de maatregelen om de wendbaarheid binnen het contract voor onbepaalde tijd te vergroten en het gebruik van flexibele contracten te beperken. Het komt in feite neer op de ook al door de Wet werk en zekerheid en de Wet arbeidsmarkt in balans nagestreefde doelstelling van het verminderen van de kloof tussen vast en flex. De eerste indruk is dat het voorstel zeker de moeite waard is om te dienen als basis voor een eventuele wetswijziging, al moet, zoals de Commissie ook zelf onderkent, een en ander nog nader worden uitgewerkt en doorgedacht. Deze bijdrage vormt daartoe een eerste aanzet.

Een inconsistentie doet zich voor in het advies voor wat betreft enerzijds het voorstel tot het behoud van de preventieve ontslagtoets, met als belangrijke argument dat het voor de lager betaalde werknemer veelal geen optie zal zijn om achteraf zijn recht te moeten halen, en anderzijds het voorstel om deeltijdontslag mogelijk te maken zonder preventieve toetsing, waarbij de werknemer achteraf zijn recht moet halen bij de rechter. Het argument dat een werknemer niet snel de stap naar de rechter zal zetten, geldt in nog belangrijkere mate voor de werknemer die nog (gedeeltelijk) een arbeidsovereenkomst heeft, uit angst voor mogelijke repercussies door de werkgever. De mogelijkheid van een deeltijdontslag past bij het vergroten van de interne wendbaarheid voor werkgevers en het afremmen van externe flexibiliteit, maar deze zou wat mij betreft ook via de preventieve 
toetsing door het UWV dienen te verlopen. Het UWV is bij uitstek geschikt om de bedrijfseconomische omstandigheden te toetsen die een dergelijk deeltijdontslag moeten rechtvaardigen.

Het voorstel om de arbeidsovereenkomst zonder meer te ontbinden indien de werkgever dat wenst wegens in de persoon van de werknemer gelegen redenen, acht ik niet alleen in het belang van de wendbaarheid van de organisatie, maar ook in het belang van de werknemer. Wel moet daar, zoals de Commissie ook voorstelt, een adequate vergoeding tegenover staan wanneer een redelijke grond ontbreekt. Met de toevoeging van nog een extra vergoeding aan het ontslagrecht, wordt het er niet eenvoudiger op. Om die eenvoud - voor zover die al bestaat - zo min mogelijk aan te tasten en de vergoeding in te passen in het huidige ontslagsysteem, dient gewaakt te worden voor verschillen in hoogte tussen de huidige billijke vergoeding wegens ernstig verwijtbaar handelen en de nieuw voorgestelde vergoeding wegens het ontbreken van een redelijke grond. Een manier om dat te voorkomen is om ook de vergoeding wegens het ontbreken van een redelijke grond te kenschetsen als een billijke vergoeding wegens ernstig verwijtbaar handelen, zoals we die thans kennen. Net zoals bij de billijke vergoeding van artikel 7:681 BW zou bij het ontbinden zonder redelijke grond, aangenomen kunnen worden dat de ernstige verwijtbaarheid van de werkgever een gegeven is en zit ingebakken in de toepassingsvoorwaarde voor die vergoeding. In dat geval kan aangesloten worden bij de begrotingsmethodiek voor de billijke vergoeding zoals we die kennen uit de New Hairstyle-beschikking. Een andere mogelijkheid zou zijn het invoeren van een formule aan de hand waarvan zowel de billijke vergoeding wegens ernstig verwijtbaar handelen of nalaten wordt begroot alsook de vergoeding wegens het ontbreken van een redelijke grond.

Het is afwachten hoe het de voorstellen van de Commissie verder vergaat. De Commissie meent dat de voorstellen richting kunnen geven aan het proces dat in de komende kabinetsperioden moet leiden tot coherente en toekomstgerichte regels rondom werk. Daarbij benadrukt zij dat de problemen op de arbeidsmarkt urgent zijn en dat het kabinet op korte termijn aan de bak moet om te voorkomen dat een point of no return wordt bereikt. ${ }^{58}$ Gelet op de snelheid waarmee wetswijzigingen in het arbeidsrecht en het socialezekerheidsrecht elkaar het laatste decennium opvolgen, sluit ik niet uit dat ook dit advies tot een wetswijziging zal leiden. 